\title{
Holocene environmental history on the eastern slope of the Polar Ural Mountains, Russia
}

\author{
VLASTA JANKOVSKÁ, ANDREI A. ANDREEV AND NATA K. PANOVA
}

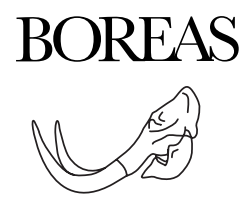

\begin{abstract}
Jankovská, V., Andreev, A. A. \& Panova, N. K. 2006 (November): Holocene environmental history on the eastern slope of the Polar Ural Mountains, Russia. Boreas, Vol. 35, pp. 650-661. Oslo. ISSN 0300-9483.
\end{abstract}

The Holocene environmental history of the eastern slope of the Polar Ural Mountains has been reconstructed using pollen, spores, algae and other microfossils from the Chernaya Gorka palsa section $\left(67^{\circ} 05^{\prime} \mathrm{N}, 65^{\circ} 21^{\prime} \mathrm{E}\right.$, $170 \mathrm{~m}$ a.s.l.). An initial oligotrophic lake was formed at the study site $c .9800-9500{ }^{14} \mathrm{C}$ yr BP. Although tundra communities dominated the vegetation in the area, birch and larch trees might have grown at lower elevations. Dry and disturbed soil habitats also occurred around the lake. Algae (mostly Pediastrum and Botryococcus) started to expand in the lake as climate gradually improved after $c .9500{ }^{14} \mathrm{C} \mathrm{yr}$ BP. However, the role of mosses (mostly Calliergon and Drepanocladus) was most important for the infilling of the lake basin. Increased temperatures and subsequent improvement of hydrological conditions resulted in vegetation changes: stands of willows developed rapidly and the role of tree birch in the local vegetation increased. The lake was completely filled at $c .8600{ }^{14} \mathrm{C} \mathrm{yr}$ BP. Peat accumulation started with Bryales mosses and, later, Sphagnum became dominant. Stands of Larix, Picea and Betula became well developed during the Boreal climate optimum. Tree birch began to spread into the tundra. Different Bryales mosses formed peat $c .8000-6500{ }^{14} \mathrm{C}$ yr BP. Cyperaceae later became the main peat-forming element. Dense spruce canopies with Larix sibirica and Betula pubescens surrounded the study site during the Atlantic period, pointing to the warmest climate during the Holocene. Summer temperatures might have been up to $3-4{ }^{\circ} \mathrm{C}$ higher than today. However, a decline of spruce and an increase of birch around $6700-6300{ }^{14} \mathrm{C}$ yr $\mathrm{BP}$ may reflect some climate deterioration. There are no dated deposits younger than $6000{ }^{14} \mathrm{C}$ yr BP. It is assumed that Subboreal climate deterioration resulted in the development of permafrost and formation of the palsa at the site. The deposits, now protruding above the surrounding terrain, were eroded by wind, water and cryogenic processes.

Vlasta Jankovská (e-mail: jankovska@brno.cas.cz), Botanical Institute, Academy of Sciences of the Czech Republic, CZ-60300 Brno, Pořičí 3b, Czech Republic; Andrei A. Andreev(e-mail: aandreev@awi-potsdam.de), Alfred Wegener Institute for Polar and Marine Research, Research Unit Potsdam, Telegrafenberg A43, D-14473 Potsdam, Germany; Nata K. Panova (e-mail: natapanova@mail.ru), Botanical Garden of Ural Branch of Russian Academy of Sciences, Yekaterinburg, Bilimbayevskaya 32a, 620134 Russia; received 15th September 2005; accepted 7th February 2006.

Our knowledge about palaeoenvironmental changes in the Eurasian Arctic, particularly in NE European Russia, has significantly increased over the past decade, with several pollen, diatom, macrofossil and insect records from the Polar Urals and adjacent regions published during the period (Andreev et al. 1998, 2001, 2005; Serebryanny et al. 1998; Koshkarova et al. 1999; Panova \& Jankovska 2000; Oksanen et al. 2001; Väliranta et al. 2001; Kultti et al. 2003; Panova et al. 2003; Paus et al. 2003; Sarmaja-Korjonen et al. 2003). Despite these studies, however, still little is known about the Holocene vegetation cover and climate changes at the NE rim of the Polar Urals (Fig. 1).

The climate fluctuations in the area have been studied dendrochronologically for many years (e.g. Shiyatov 1964, 1986; Vaganov et al. 1996), but reliable palaeoenvironmental reconstructions require high-resolution and well-dated sediment sequences containing palaeoclimatic proxy records, such as pollen and nonpollen palynomorphs. Nevertheless, high-resolution pollen, especially non-pollen palynomorph analysis of peat and/or lacustrine deposits, which could provide long-term histories of vegetation and climate dynamics in the region, has not been done previously. A palsa profile, Chernaya Gorka in the Polar Ural Mountains, was chosen for the detailed palaeoecological study because of its proximity to the treeline limit and, therefore, its potential sensitivity to climate-driven changes in the past.

This article presents the results of pollen and nonpollen palynomorph analysis of the Chernaya Gorka palsa deposits and demonstrates new possibilities for the interpretation of palynological assemblages using non-pollen microfossils, e.g. algae, fungi, rhizopods, cladocera, rotatoria, and other often neglected biological remains which can successfully be used for the precise reconstruction of past environments. Such reconstructions are important for understanding regional and local environmental trends in the high Arctic regions. Moreover, they provide a basis for prediction of the future changes there, which is especially important for the Arctic areas of West Siberia, where anthropogenic influence strongly increased during recent decades. 
Fig. 1. A. Map showing the location of the Polar Urals Mountains and the studied Chernaya Gorka site. Light shading depicts elevations of 100 $200 \mathrm{~m}$ a.s.l., while dark grey shading shows elevations $>200 \mathrm{~m}$ a.s.l. B. Schematic map showing the location of studied palsa section $(*)$ and other cited locations: 1 = Malaya Khadata Lake section (Surova 1967; Surova \& Troitsky 1971; Surova et al. 1975); 2 = Bol'shaya Lagorta River section (Surova et al. 1975); $3=$ Rai-Iz peat section (Koshkarova et al. 1999); 4 =Lake Lyadhej-To (Andreev et al. 2005).

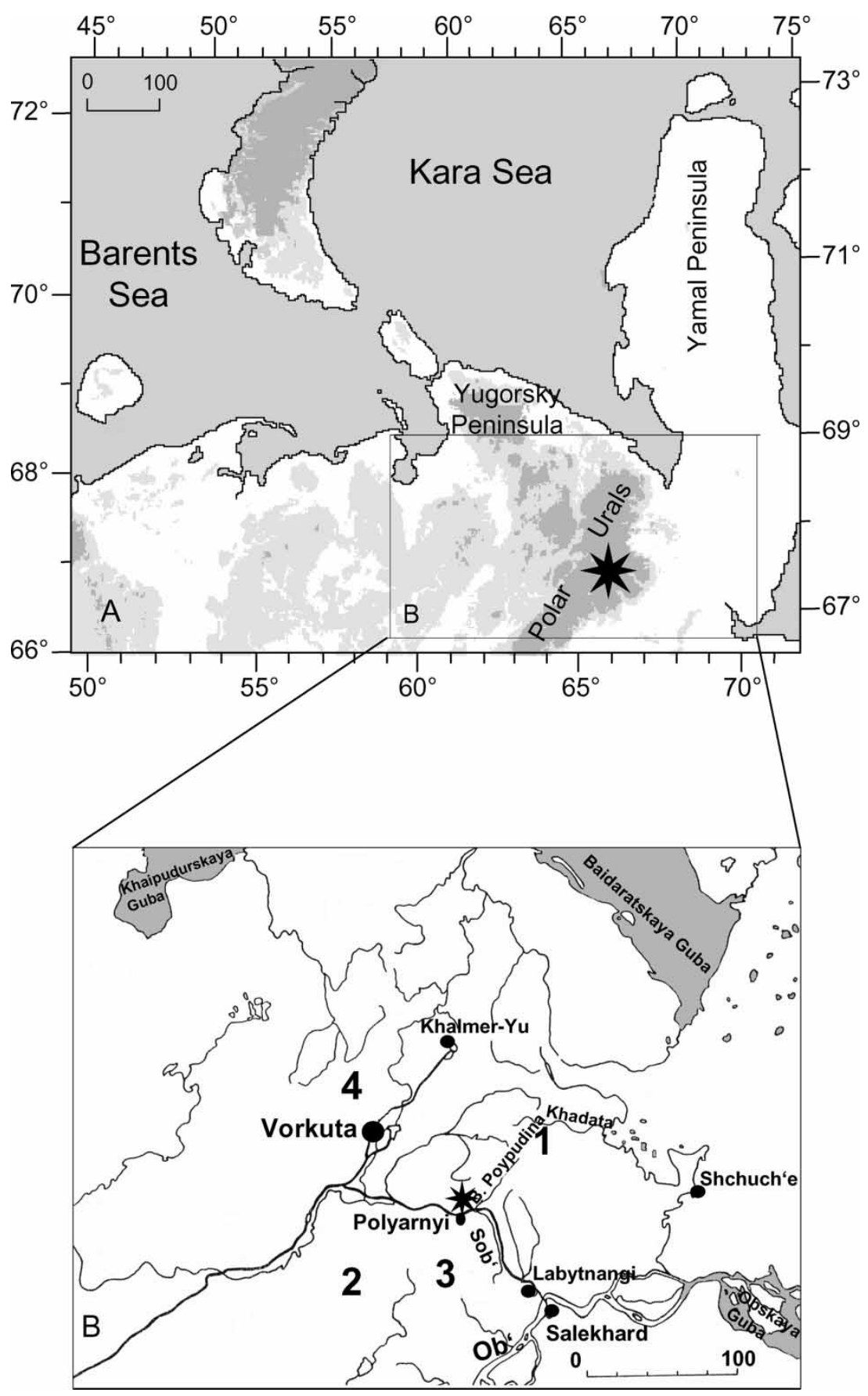

The palsa is in a phase of degradation and traces of erosion by wind, water and cryoturbation are notable. The southern side is gradually being destroyed due to thawing within the frozen core, and a small lake ( $c$. $20 \times 15 \mathrm{~m}$ ), roughly similar in size to the palsa, has been formed on the southern side. The study site is one of several solitary palsas on a wide, soggy area that is saturated by water flowing from an easterly mountain ridge. Most of these palsas are also in a state of degradation. 
The surface on the top of the studied palsa is mostly devoid of vegetation, with only rare Ledum palustre, Empetrum hermaphroditum, Arctostaphylos uva-ursi, Arctous alpina and some other herbaceous species. The vegetation on the sides is denser and is formed primarily by Ledum palustre, Rubus chamaemorus and Betula nana, with an undergrowth of mosses and lichens. Distinct dominant taxa at the edge of the lake and along the outflow are Salix lanata, S. lapponum and S. phylicifolia, with a herb layer of Polemonium coeruleum, Polygonum bistorta, Trollius europaeus, Veratrum lobelianum, Carex sp., and other species. Sphagnum prevails among the submerged vegetation advancing from the borders of the pool, and Eriophorum russeolum distinctly dominates the herbs.

Tundra vegetation occurs on the landscape surrounding the palsa, with the predominance of Betula nana, along with Ledum palustre, Vaccinium vitis-idaea, V. uliginosum, Andromeda polifolia and Arctostaphylos uva-ursi. A rich lichen (Cetraria islandica, C. delisei, C. cucullata, C. nivalis, Cladonia alpestris, C. rangiferina, C. sylvatica, Alectoria sp. div., Thamnolia vermicularis and Dactylina arctica) and moss (Aulacomnium turgidum, Hylocomium splendens and Pogonatum sp.) cover is noticeable.

Only sparse Betula tortuosa and rare Larix sibirica grow in the area surrounding the site. Denser stands of L. sibirica and B. pubescens with fewer Picea obovata were observed $c .1 \mathrm{~km}$ to the east at a lower elevation. Park spruce-larch and spruce-birch forests cover the eastern slopes of the Polar Ural Mountains, and are generally limited to areas below $150-160 \mathrm{~m}$ a.s.l. (Shiyatov 1964, 1996).

Climate characteristics from the nearby Sob' River valley (Shiyatov 1964; Kuvchinova 1968) can also be used for the Chernaya Gorka locality. Average January temperature is $-22^{\circ} \mathrm{C}$, while average temperature in July is $+12^{\circ} \mathrm{C}$. Mean annual precipitation is approximately $600 \mathrm{~mm}$. In such climatically extreme regions, the extent and depth of permafrost and the rate of summer thawing are of utmost importance for the vegetation, as well as the thickness of snow cover and its persistence into the growing period. Strong winds are also a limiting factor, since they cause the local accumulation of great snow masses and may suppress the height of the vegetation cover, or even completely destroy it, by means of the wind-driven frozen snow (i.e. the 'grinding effect').

\section{Material and methods}

The maximum thickness of the organic deposit within the palsa is $2.15 \mathrm{~m}$. The thickest profile was sampled from an open pit dug to the southern side of this palsa on 1 August 1994. Palynological analyses were carried out at 5-cm intervals. Processing included $\mathrm{KOH}$ deflocculation and treatment with
HF followed by acetolysis and the mounting of pollen samples in glycerine. A minimum of 600 pollen grains were counted; spores and non-pollen palynomorphs were tallied in addition. Pollen percentages were calculated based on the total pollen sum. The percentage of spores was based on the sum of pollen and spores, the percentage of algae on the sum of pollen and algae, and the percentages of other identified palynomorphs on the sum of pollen and sums of other identified palynomorphs (separately for each group).

TILIA and TILIAGRAPH were used for graphing the pollen data (Grimm 1991). Pollen zonation was done by visual inspection of the pollen percentage diagram.

Four samples (Table 1) were radiocarbon-dated at the Radiocarbon Laboratory of the Institute of Physics, Silesian Technical University in Gliwice, Poland. All discussed dates are given in the radiocarbon years.

\section{Results}

\section{Radiocarbon chronology}

A piece of Salix wood, likely a root (V. Čulíková, pers. comm. 1996), from $205 \mathrm{~cm}$ depth is radiocarbon-dated to the end of the Preboreal period, at about 92009500 yr BP (Table 1). The lowermost limnic sediments of Chernaya Gorka (215-205 cm depth) contain relatively large amounts of Artemisia and Chenopodiaceae, indicating a rather dry and cold environment. Similar pollen spectra occur in the Holocene records of northern Eurasia (e.g. Surova et al. 1975; Khotinskiy 1984; Velichko et al. 1997; Andreev et al. 2002, 2003, 2004) and are dated to $9800-9500{ }^{14} \mathrm{C}$ yr BP. Taking into consideration the radiocarbon age of the Salix wood and pollen composition at the same depth, we therefore suggest that organic accumulation at the site began not earlier than $9800-9500{ }^{14} \mathrm{C}$ yr BP.

Limnic sedimentation continued until the beginning of the Boreal period. Although two radiocarbon ages (Table 1) from moss peat $(180 \mathrm{~cm})$ and Sphagnum peat $(150 \mathrm{~cm})$ are inversed, they are nearly identical, taking into consideration the statistical errors. We assume that peat accumulation started around $8800{ }^{14} \mathrm{C}$ yr BP. Similar ages of the basal peat layers: $8670 \pm 100 \mathrm{yr}$ BP (Tln-85) from the Malaya Khadata Lake section (Surova et al. 1975) and $8530 \pm 40 \mathrm{yr}$ BP (SOAN3028) from the Rai-Iz peat section (Koshkarova et al. 1999) have been reported from adjacent areas.

An oligotrophic, Sphagnum-dominated peat bog developed during the Boreal and the beginning of the Atlantic periods. A shift to Cyperaceae-dominated peat was radiocarbon-dated to $6000 \mathrm{yr}$ BP $(15-20 \mathrm{~cm}$ depth), indicating the transition from moss peat accumulation to sedge peat during the middle Atlantic period. This likely occurred c. $6700{ }^{14} \mathrm{C}$ yr BP, as 
Table 1. Radiocarbon ages $\left({ }^{14} \mathrm{C}\right.$ yr $\left.\mathrm{BP}\right)$ from the studied palsa section.

\begin{tabular}{|c|c|c|c|}
\hline $\begin{array}{l}\text { Laboratory } \\
\text { no. }\end{array}$ & $\begin{array}{l}\text { Depth, } \\
\text { cm }\end{array}$ & Dated material & $\begin{array}{l}{ }^{14} \mathrm{C} \text { ages, } \\
\text { yr BP }\end{array}$ \\
\hline Gd-9938 & $15-20$ & Cyperaceae peat & $6020 \pm 200$ \\
\hline Gd-10776 & 150 & $\begin{array}{l}\text { Slightly decomposed } \\
\text { Sphagnum peat }\end{array}$ & $8720 \pm 180$ \\
\hline Gd-9947 & 180 & Strongly decomposed moss peat & $8620 \pm 270$ \\
\hline Gd-9935 & 205 & Salix wood (probably a root) & $9230 \pm 280$ \\
\hline
\end{tabular}

inferred from the Betula sect. Albae pollen peak. Two radiocarbon dates from the Malaya Khadata peat section: $6745 \pm 70$ (Tln-84) and $6315 \pm 70(T \ln -64)$ yr BP date a similar peak to approximately $6700-6300$ ${ }^{14} \mathrm{C}$ yr BP (Surova et al. 1975). Unfortunately, the uppermost surface of the studied palsa has been destroyed by wind denudation and records much younger than $6000{ }^{14} \mathrm{C}$ yr BP are missing.

\section{Pollen zones}

The spectra in the pollen zone I (PZ-I, 215-205 cm; Fig. 2) are dominated by Betula, Cyperaceae and Poaceae pollen. Pollen of Artemisia and Chenopodiaceae are also characteristic. PZ-II $(205-175 \mathrm{~cm})$ is notable for an increase in Salix pollen contents (in the lower part of PZ-II) and Betula sect. Albae (in the upper part of PZ-II), while Poaceae and Artemisia are gradually decreased. High amounts of Bryales spores, rhizopods (Assulina, Arcella) and algae remains (Pediastrum, Botryococcus, Tetraedron, Scenedesmus) are also noticeable in the zone. PZ-III $(175-80 \mathrm{~cm})$ is characterized by decreases in Poaceae and Salix percentages and significant increases in Cyperaceae and Thalictrum percentages. Thalictrum, Filipendula and Potentilla appear exhibiting an increase similar to that for the fern spores. A Sphagnum peak also occurs in this zone. The upper part of the zone (starting from $110 \mathrm{~cm}$ ) is characterized by a gradual increase in Picea pollen percentages. PZ-IV $(80-0 \mathrm{~cm})$ is notable for high amounts of Picea pollen in the spectra. An increase in Betula sect. Albae pollen is noticeable in the middle part of PZ-IV.

\section{Abundance of some pollen types in surface samples}

\section{Larix}

In the Labytnangi-Yamal Peninsula transect of surface pollen samples (unpublished), we found a very strong underrepresentation of Larix pollen compared to its occurrence in modern vegetation. Similar results have been obtained by Levkovskaya (1967) and Surova \& Troitsky (1971). Larix pollen was encountered very rarely, despite the fact that it is the only tree currently present in the area. In the forest-tundra zone north of the village of Obskaya, Larix pollen is rarely found even directly under living trees. These observations imply that even rare occurrences of Larix pollen in the pollen records indicate its local presence in the landscape.

\section{Betula}

$B$. sect. Albae-type (tree birch) pollen are produced by $B$. pubescens and B. tortuosa. Distinguishing between the pollen types (B. sect. Nanae and B. sect. Albae) is problematic in some cases; in this study, all problematic pollen grains have been assigned to $B$. sect. Albae-type. Surface pollen samples collected in different vegetation habitats show that pollen of $B$. sect. Albae-type always dominates over $B$. sect. Nanae-type (Jankovská unpublished). Thus, B. sect. Nanae-type is usually underrepresented in the spectra. It is likely that pollen of the low/dwarf shrub $B$. nana falls directly to the ground and is not spread as readily by wind as the taller $B$. tortuosa or B. pubescens.

\section{Salix}

Numerous Salix pollen in the surface samples were found only under living willow stands. Little or no pollen was found at short distances from low creeping dwarf willows. This finding implies that a large abundance of Salix pollen indicates the dominance of willow in the local vegetation.

\section{Alnus fruticosa (A. viridis)}

This shrub spreads its pollen relatively easily. In the surface transect, A. fruticosa pollen was found several hundred metres distant from the plants. Single pollen grains in the pollen record therefore indicate the presence of this species in the wider surroundings, and abundant grains indicate its presence in close vicinity to the sampling site.

\section{Pinus sylvestris and P. sibirica}

Pollen grains of these trees are present in all surface samples from the northern taiga to the northern tundra. However, the nearest living trees are more than $100 \mathrm{~km}$ south of the most southern surface sample site. Long distance transport of Pinus pollen should thus be taken into account in the interpretation of all pollen diagrams. Very few Pinus trees and/or longdistance pollen transport are capable of creating the socalled pine-forest pollen spectrum in an open tundra landscape. 


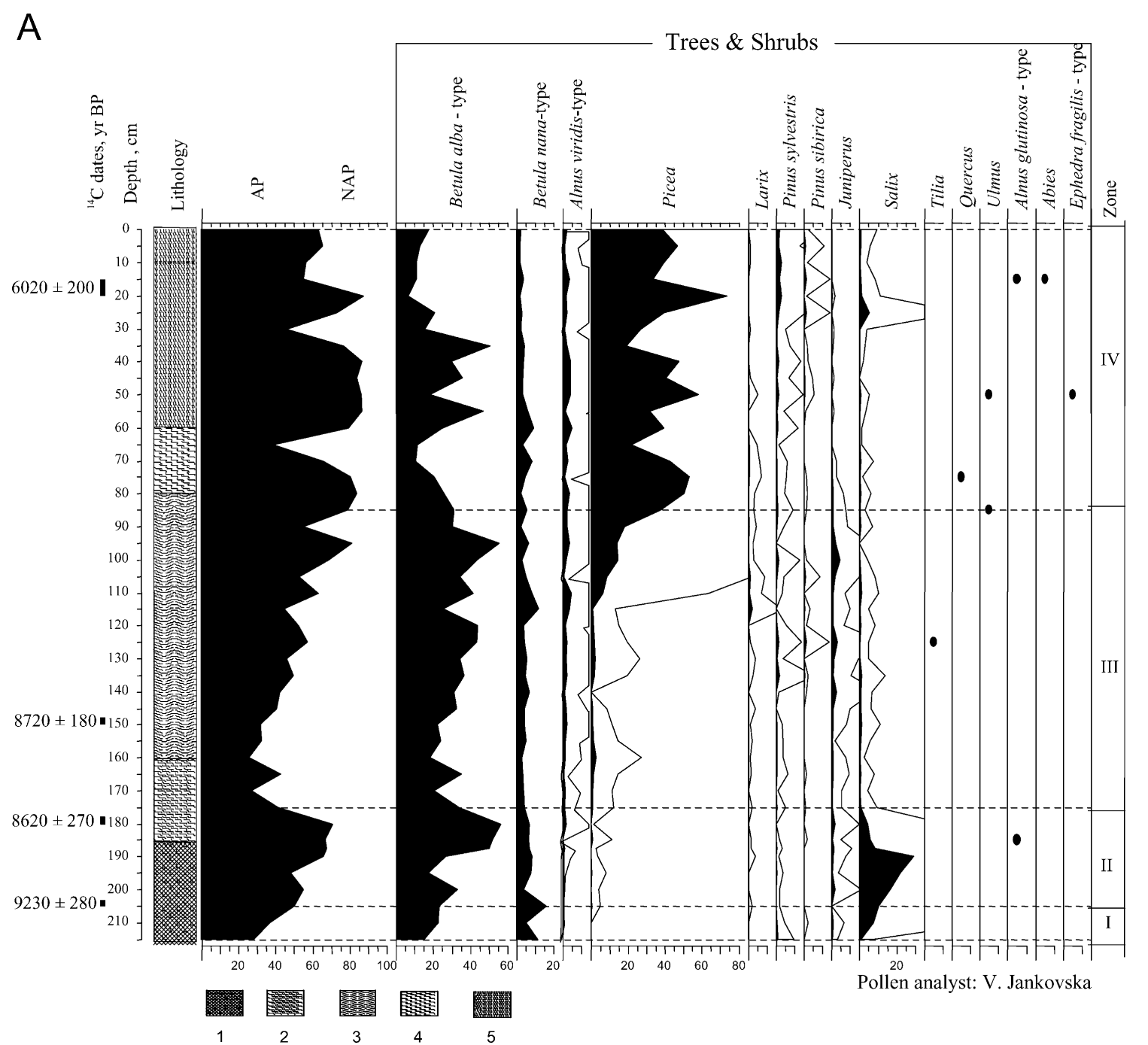

Fig. 2. Pollen, spore and non-pollen palynomorphs diagram of the Chernaya Gorka palsa section. Taxa are expressed as percentages (black), low percentages exaggerated 10 times as empty curves, minor taxa (less than $2 \%$ ) as dots: $1=$ lacustrine sediments; $2=$ strongly decomposed green moss peat; $3=$ Sphagnum dominated peat; $4=$ slightly decomposed green moss peat; $5=$ herb peat. A. Percentage diagram of AP/NAP, trees, and shrubs pollen. B. Percentage diagram of herb pollen. C. Percentage diagram of spores and palynomorphs. 


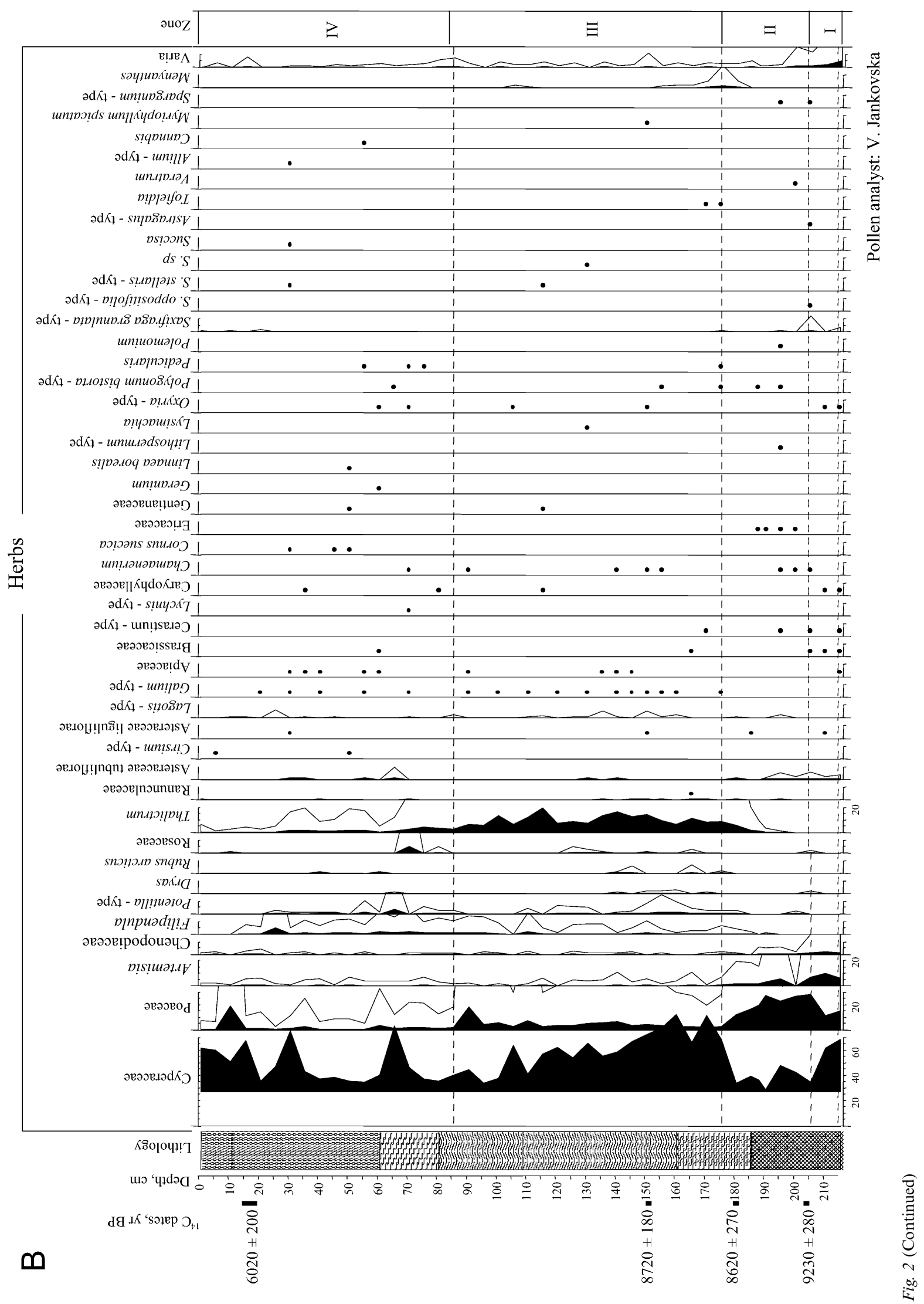




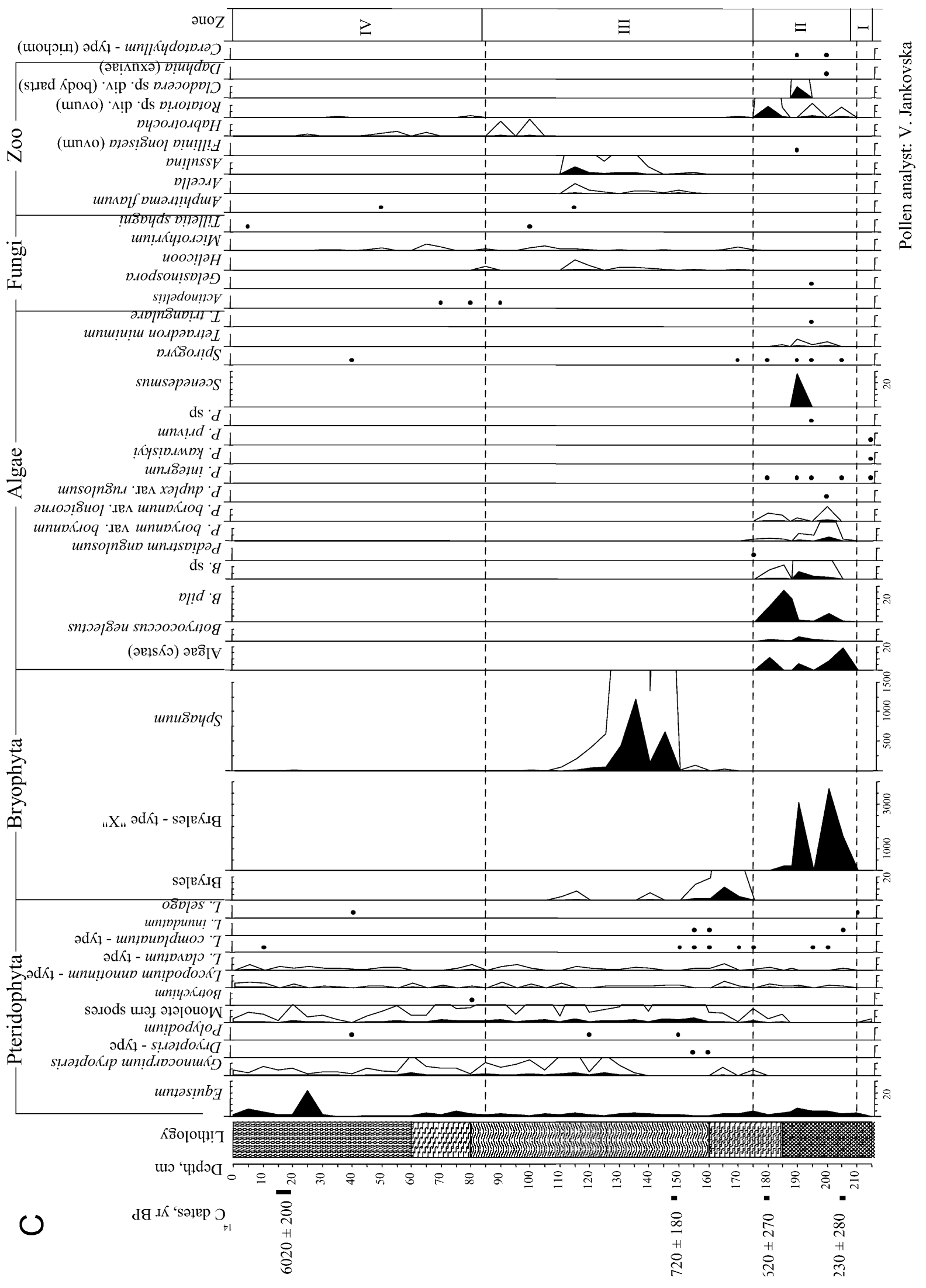




\section{Palaeoecological reconstruction and discussion}

An initial stage, PZ-I, c. $9800-9500{ }^{14}$ C yr BP

Increased temperatures towards the end of the Lateglacial period drove the thawing of glaciers, snow patches and permafrost. The thaw-generated meltwater accumulated during the summer on the deep, impermeable permafrost in places lacking an outlet. At the Chernaya Gorka site, the initial water body was probably formed $9800-9500{ }^{14} \mathrm{C}$ yr BP. In its initial phase, it was most likely completely devoid of aquatic vegetation, but Sparganium (cf. angustifolium) appeared and it is likely that Eriophorum (E. russeolum or E. scheuchzerii) began to penetrate from the rims of the lake. The only microfossils encountered are sporadic colonial green algae (Pediastrum kawraiskyi, $P$. integrum and $P$. privum). Although rare, they unambiguously indicate the existence of very cold oligotrophic water. For example, $P$. integrum was found in several surface pollen samples from different locations in the subarctic zone (moist tundra habitats) and $P$. kawraiskyi in samples from very shallow water habitats, e.g. at Kharasavei on the northern Yamal Peninsula within the zone of northern tundra. Thus, we assume that the initial water body was a small, shallow lake with very cold oligotrophic water.

Rather high amounts of Salix pollen suggest that the lake was surrounded by a rim of willows. However, the dominant vegetation of the wider surroundings probably consisted of tundra communities: dwarf-shrub tundra (Betula nana, dwarf Salix species, Ericaceae) and shrub tundra (taller Salix species, Betula tortuosa) with an undergrowth of lichens and mosses. Species from Astragalus, Allium, Cardamine, Cerastium, Chamaenerium, Dryas, Oxyria, Saxifraga, Veratrum, Polygonum, Polemonium, Equisetum and, in greater numbers, Caryophyllaceae, Cyperaceae, Asteraceae grew in the area. Grasses were also very common. Relatively large amounts of Artemisia and Chenopodiaceae indicate habitats with dry microenvironments and/or disturbed soils.

Considering the marked underrepresentation of certain pollen types in the assemblage, even the extremely low Larix values allow us to assume the occurrence of some larch trees not too far away from the study area. Tree birch and larch forests probably grew in close vicinity to the site. The negligible pollen values of Picea, Pinus sylvestris and P. sibirica are ascribed to long-distance transport. Macrofossil remains of Picea obovata dated to $9370 \pm 40{ }^{14} \mathrm{C}$ yr BP (SOAN-3105) have been found at the Rai-Iz site (Koshkarova et al. 1999), suggesting that spruce might have been growing in the Polar Urals region by 9400 ${ }^{14} \mathrm{C}$ yr BP, at least in the southern parts. The northern limits of the pine species were even farther to the south in the past than today.
Late Preboreallearly Boreal, PZ-II, c. 9500-8600

${ }^{14}$ C yr BP

The original small lake was for the greater part filled in during the late Preboreal/early Boreal, starting c. 9500 ${ }^{14} \mathrm{C}$ yr BP. Algae started to expand in the lake as climate gradually improved. Pediastrum integrum, $P$. boryanum var. longicorne and Botryococcus pila are primary indicators, growing mainly in small, cold, oligotrophic lakes (Jankovská \& Komárek 2000; Komárek \& Jankovská 2001). These taxa are followed by Pediastrum boryanum var. boryanum, $P$. duplex var. rugulosum, Tetraedron minimum (sporadically $T$. triangulare), Scenedesmus and Spirogyra. The present habitat of Botryococcus neglectus is a natural mesotrophic environment. The presence of an aquatic environment is also supported by eggs of rotatoria (cf. Fillinia longiseta, Rotatoria sp. div.), exuviae of Daphnia and different parts of cladocera.

For the infilling of the lake, the role of mosses (Calliergon, Drepanocladus and others) was most important. Towards the end of the Preboreal and in the Boreal, Menyanthes trifoliata, Comarum palustre and Cyperaceae also contributed to the infilling. The occurrence of Menyanthes confirms that temperatures were higher than present (Surova et al. 1975).

Increased temperatures and subsequent improvement of hydrological conditions (thawing of glaciers and permafrost) resulted in vegetation changes. A gradual decrease of Artemisia and Chenopodiaceae pollen percentages indicates that the dry and disturbed habitats disappeared in the area surrounding the lake. A dramatic increase in Salix pollen percentage could be related to locally moister conditions. Stands of willows (most likely Salix lanata, S. glauca, S. lapponum, and possibly $S$. phylicifolia) developed. Cyperaceae and Poaceae grew in the vicinity of the lake. The increasing role of the tree birch in the local vegetation is also characteristic of this period. Alnus fruticosa and Picea probably were not present in the area, but they began to spread in the surrounding regions (Surova et al. 1975; Koshkarova et al. 1999).

\section{Middle Boreallearly Atlantic, PZ-III, c. 8600-8000 ${ }^{14}$ C yr BP}

It is difficult to date the upper boundary of this interval. However, it is known that the early Atlantic sediments in the Polar Ural Mountains are characterized by the dramatic increase of Picea pollen percentages (Surova et al. 1975). Such an increase in the palsa peat section from the vicinity of the Malaya Khadata Lake was radiocarbon-dated to $7960 \pm 100$ (Tln-86) yr BP. Another ${ }^{14} \mathrm{C}$ age, $7790 \pm 80$ (Tln-40) yr BP, from a section in the upper part of the Bol'shaya Lagorta River valley dates the sediments to slightly above the Picea peak. Thus, we may assume that the Picea pollen 
increase at the studied palsa started not much earlier than $8000{ }^{14} \mathrm{C}$ yr ago.

The Bryales spores present at the beginning of this period, c. $8600{ }^{14} \mathrm{C}$ yr ago, are of a different type from those in the preceding limnic phase, indicating that mosses which formed peat are different from the mosses that dominated during the limnic stage. Later Sphagnum mosses became the basic peat-forming element. Peat consisting mainly of Sphagnum was formed up to the late Boreal/early Atlantic, approximately $8000{ }^{14} \mathrm{C}$ yr BP. The rhizopods (Arcella, Assulina and Amphitrema flavum) as well as fungi remains (Helicoon and Microthyrium) are typical of Sphagnum-dominated peat tundra. As observed on Spitsbergen by V. Jankovská (unpublished), remains of Tilletia sphagni (fungi parasailing on Sphagnum) indicate the local occurrence of Sphagnum even though its spores were not found. Remains of Habrotrocha (rotatoria) are another important indicator of an oligotrophic Sphagnum-dominated wetland.

Climate amelioration enabled the spread of more cold-sensitive vegetation. Stands of Larix, Picea, and Betula of forest-tundra and northern-taiga character developed during the Boreal. Tree birch began to spread in the tundra. Light conditions favourable for the spread of Juniperus and Alnus fruticosa still persisted. Favourable hydrologic soil conditions enabled the spread of Filipendula, Thalictrum, Polygonum bistorta, Cyperaceae and probably Lagotis cf. uralensis. Primordial natural moist meadows were formed. Enhanced moisture availability also led to the spreading of fern. A regular occurrence of Gymnocarpium dryopteris (identified by J. van Leeuwen and S. Peglar, University of Bern) should be noted. Menyanthes trifoliata and Comarum palustre grew in wetlands, where Sphagnum was common. These vegetation changes occurred in the Polar Ural Mountains during the Boreal climate optimum and are similar in character to those in other parts of northern Eurasia (e.g. Khotinskiy 1984; Velichko et al. 1997; Andreev et al. 2002, 2004, 2005).

Early/middle Atlantic, PZ-IV, c. $8000-5800{ }^{14}$ C yr BP

At the beginning of the interval, various Bryales mosses formed peat. Beginning in the middle Atlantic, Cyperaceae became the main peat-forming element. Dense canopies of spruce stands with Larix sibirica and Betula pubescens surrounded the study site. This scenario correlates well with other palaeoecological data from the Polar Urals (Surova \& Troitsky 1971; Surova et al. 1975; Koshkarova et al. 1999) and from other arctic and subarctic areas of northern Eurasia (e.g. Velichko et al. 1997; MacDonald et al. 2000; Andreev et al. 2002, 2004).

The forests in the lower valleys of the Polar Urals were similar to the northern taiga type, and in lower altitudes, possibly to the middle taiga type. Forests attained higher altitudes and latitudes than today. Surova \& Troitsky (1971) comparing the Polar Ural forests during the Atlantic period to the present-day forests on the northern Ural Mountains conclude that summer temperatures were $3-4^{\circ} \mathrm{C}$ higher than today in northern regions of the Ural Mountains, and glaciers fully melted and disappeared. Similar climate parameters based on pollen and chironomid records were reconstructed for the northwestern rim of the Polar Ural Mountains (Andreev et al. 2005).

Spruce act to suppress the less competitive larch at lower altitudes and latitudes. The occurrence of Larix is limited primarily by light conditions, and therefore prevails over spruce only at higher altitudes and latitudes where spruce is less dominant. The decrease of Larix pollen at Chernaya Gorka during the later part of the Middle Holocene points to a decline in the proportion of larch in the surrounding spruce forests. The decline of Juniperus pollen indicates that juniper was also light-limited in the shady spruce forests. A distinct northward shift of all woody species distributions took place during the Atlantic period. This is supported by isolated pollen grains of Ulmus and Quercus, as well as by increased Pinus pollen values. Neither Ulmus nor Quercus grew at the study site at that time, and we assume that both Pinus sibirica and $P$. sylvestris pollen were transported from a long distance, as well as Abies sibirica. The taiga character of the forests in the Polar Ural Mountains during the Atlantic period is also supported by herb pollen such as Linnaea borealis, Cornus suecica and increased fern spores. Conspicuous is the abundance of Gymnocarpium dryopteris and various Lycopodium species. The Cannabis pollen came from long-distance transport and may be used as additional evidence of the northward shift of species distribution limits.

Surova et al. (1975) point to a cooling in the Polar Ural Mountains in the middle Atlantic period, inferred from a decline in spruce pollen and an increase in birch pollens. Two radiocarbon dates from the Malaya Khadata site: $6745 \pm 70$ (Tln-84) and $6315 \pm 70$ (Tln64) yr BP date this interval to roughly $6700-6300{ }^{14} \mathrm{C}$ yr BP, which correlates well with palaeodata from arctic and subarctic areas of northern Eurasia (e.g. Velichko et al. 1997; Andreev \& Klimanov 2000; Andreev et al. 2002, 2004 and references therein). The peaks of birch pollen in PZ-IV most likely have a similar age. A radiocarbon date of $6020 \pm 200{ }^{14} \mathrm{C} \mathrm{yr}$ BP from the overlying peat layer confirms such a conclusion.

The highest values of Picea pollen in the peat sediments, dated to $c$. $6200-5800{ }^{14} \mathrm{C}$ yr BP, suggest the maximum distribution of spruce in the region and the warmest climate at the study site during the Holocene. The pollen records and radiocarbon ages $(6280 \pm 70(T \ln -83))$ and $5680 \pm 120(T \ln -56))$ from the Malaya Khadata site reflect a similar environment (Surova et al. 1975). 
Deposits much younger than $6000 \mathrm{yr}$ BP are absent at Chernaya Gorka, probably because of erosion of the palsa. According to Surova et al. (1975), degradation of the spruce forest in the Polar Ural Mountains took place during the Subboreal as a result of climate deterioration. The forest stands retreated farther from the valleys of the Polar Ural Mountains and tundra communities spread once again. The increased proportion of Pinus pollen can be interpreted as being due to long-distance transport from enhanced atmospheric circulation and/or movement of pine trees to the north. They assume a cooling of the climate and an increase of precipitation (particularly snow). The thicker snow cover resulted in the degradation of forests and in the resumed formation of mountain glaciers in the Polar Urals Mountains (Surova et al. 1975). A similar vegetation development is reconstructed from the preliminary pollen analysis of Chernyi Ruchey brook and Utinoye Lake (V. Jankovská, unpublished).

\section{Local palsa development}

According to Surova et al. (1975), the freezing of peat bogs in the Polar Ural Mountains started prior to 2500 ${ }^{14} \mathrm{C}$ yr BP. The formation of permafrost in conditions of heavy water logging resulted in the upheaval of peat bogs and the formation of cryogenic structures of the palsa type. Subsequently, peat formation on the palsa stopped and the section elevated above the terrain became exposed to wind erosion, leading to degradation of the palsa. The conditions responsible for the development of vegetation and the extent and form of the palsa towards the end of the Atlantic can only be speculated upon because of missing late Holocene deposits. A feasible assumption is that peat growth continued during the Subboreal when the climate turned colder, but also that increasingly more of the peat became frozen. Eventually, the core remained frozen even during the summer, protected from thawing by the insulating outer peat layers. The growing ice then pushed the lake and peat deposits upwards, and a classic palsa was formed.

The gradual decline and disappearance of spruce forests in the valleys of the Polar Ural Mountains during the Subboreal period under conditions of cooling opened up the landscape, the palsa hence becoming exposed to the devastating effects of the deteriorating climate. The uppermost surface and slopes of the palsa became rather distant from the ground-water level, and peat formation stopped. Surficial peat layers gradually dried out during the summer, cracks were formed and mineralization took place. The sediment on top of the palsa protruding above the snow was exposed to wind erosion in winter. In addition, the originally frozen core of the palsa started thawing on the south side during summer. Thus, the south-exposed slope of the palsa thawed and a pool was formed. The eroding palsa gradually collapsed into this pool. At present, sub- merged vegetation in the pool (mostly Sphagnum and Eriophorum russeolum) forms new peat deposits. The peat deposits of the original palsa are disintegrated and have been redeposited (collapsing in whole blocks, washing out by rain, blowing off by wind) in the present lake environment, mixed with pollen produced by recent vegetation.

\section{Conclusions}

An initial oligotrophic lake, formed c. $9800-9500{ }^{14} \mathrm{C}$ $\mathrm{yr}$ BP, was surrounded by a rim of willows, but tundra communities dominated the vegetation in the area. Dry microenvironments and disturbed soil habitats supported Artemisia and Chenopodiaceae. Tree birch and larch might have grown in low elevations close to the lake.

The original lake basin started to fill in $c .9500{ }^{14} \mathrm{C}$ yr BP. Algae (mostly Pediastrum and Botryococcus) started to expand in the lake coincident with climate amelioration. However, mosses (mostly Calliergon and Drepanocladus) were most important for the lake infilling, which finished $c .8600{ }^{14} \mathrm{C}$ yr BP. When the lake almost completely disappeared, Menyanthes trifoliata, Comarum palustre and Cyperaceae also contributed to the infilling. Climate amelioration also resulted in vegetation changes around the lake as willow stands strongly developed and the role of tree birch increased.

Peat accumulation started c. $8600{ }^{14} \mathrm{C}$ yr BP with Bryales mosses; later Sphagnum became dominant. Peat mainly consisting of Sphagnum was formed up to $c .8000{ }^{14} \mathrm{C}$ yr BP. The continuously rising temperatures enabled the spread of more climatically and hydrologically demanding vegetation. Tree birch began to spread in the tundra. Stands of Larix, Picea and Betula became well developed during the Boreal climate optimum.

Various Bryales mosses formed peat c. 8000-6500 ${ }^{14} \mathrm{C}$ yr BP; later Cyperaceae became the main peatforming element. Dense canopies of spruce stands with Larix sibirica and Betula pubescens surrounded the study site during the Atlantic period. Summer temperatures may have been up to $3-4^{\circ} \mathrm{C}$ higher than today. A decline in spruce and an increase in birch at $c$. $6700-6300{ }^{14} \mathrm{C}$ yr BP point to some cooling at that time.

Deposits dated younger than $6000{ }^{14} \mathrm{C}$ yr BP are absent at Chernaya Gorka, probably because of wind erosion. Climate probably became colder during the Subboreal period, supporting the development of permafrost that resulted in the upheaval of the lake and peat sediments. When the palsa formed, peat accumulation stopped at the site. The deposits, protruding above the surrounding terrain, were subjected to erosion by wind, water and cryogenic action.

Such reconstructions are important for understanding regional and local environmental trends in the high 
Arctic regions. Moreover, they provide a basis for prediction of the future changes there, which is especially important for the Arctic areas of West Siberia, where anthropogenic influence has strongly increased during recent decades.

Pollen and non-pollen microfossils have been successfully used in this study for the precise reconstruction of local palaeoenvironments demonstrating new possibilities for the interpretation of palynological assemblages. It is especially important for understanding regional and local environmental trends in swampy regions of West Siberia, where paludification processes are common.

Acknowledgements. - This study was supported by grant 206/96/1223 of the Czech Republic Grant Agency for carrying out fieldwork in Russia, for radiocarbon dating and for laboratory work of $\mathrm{V}$. Jankovská. Fieldwork was also supported by an RFFI grant RFFN96-05-64129 to N. K. Panova. We thank Professor S. A. Mamaev (Yekaterinburg Botanical Garden, RAS), Professor V. N. Bolshakov and Dr. S. G. Shiyatov (Yekaterinburg Institute of Plant and Animal Ecology; RAS) as well as the staff of the Labytnangi Field Station (especially Dr. Yu. M. Malafeev and V. G. Stroh) for their kind help during fieldwork. Particular thanks are extended to T. A. ZhabraevaMalafeeva for organizing logistical details. V. Jankovská is grateful to Mr. and Mrs. Kifyak (village Polarny) for physical and moral support during the fieldwork in the Polar Ural Mountains region, as well as Drs. M. N. Uskov and T. F. Koroleva, who helped her during extreme conditions. We also thank Dr. W. O. van der Knaap (University of Bern, Switzerland) and Professor H. Wright, Jr. (Minnesota, USA) for valuable comments and for improving the language of the first manuscript draft. Drs J. Hahne and D. Peteet are thanked for helpful comments on the first version of the manuscript and an anonymous reviewer for helpful comments on the second version. Special thanks go to Heather Heuser (University of Washington) for her comments and linguistic improvements of the final manuscript.

\section{References}

Andreev, A. A. \& Klimanov, V. A. 2000: Quantitative Holocene climatic reconstruction from Arctic Russia. Journal of Paleolimnology 24, 81-91.

Andreev, A. A., Manley, W. F., Ingólfsson, Ó. \& Forman, S. L. 2001: Environmental changes on Yugorsky Peninsula, Kara Sea, Russia, during the last 12,800 radiocarbon years. Global and Planetary Change 31, 253-262.

Andreev, A. A., Siegert, C., Klimanov, V. A., Derevyagin, A. Y., Shilova, G. N. \& Melles, M. 2002: Late Pleistocene and Holocene vegetation and climate changes in the Taymyr lowland, Northern Siberia reconstructed from pollen records. Quaternary Research 57, $138-150$.

Andreev, A. A., Tarasov, P. E., Romanenko, F. A., Sulerzhitsky L. D. \& Terekhov, K. I. 1998: Vegetation on the west coast of Baidaratskaya Guba during the Late Pleistocene and Holocene. Stratigraphy and Geological Correlation 6, 520-525.

Andreev, A. A., Tarasov, P. E., Siegert, C., Ebel, T., Klimanov, V. A., Bobrov, A. A., Melles, M., Dereviagin, A. Y. \& Hubberten, H.-W. 2003: Vegetation and climate changes on the northern Taymyr, Russia during the Upper Pleistocene and Holocene reconstructed from pollen records. Boreas 32, 484-505.

Andreev, A. A., Klimanov, V. A., Siegert, C., Melles, M., Lisitsina, O. M. \& Hubberten, H.-W. 2004: Vegetation and climate changes around the Lama Lake, Taymyr Peninsula during the Late Pleistocene and Holocene reconstructed from pollen records. Quaternary International 122, 69-84.
Andreev, A. A., Tarasov, P. E., Ilyashuk, B. P., Ilyashuk, E. A., Cremer, H., Hermichen, W.-D., Hubberten, H.-W. \& Wischer, F. 2005: Holocene environmental history recorded in the Lake Lyadhej-To sediments, Polar Urals, Russia. Palaeogeography, Palaeoclimatology, Palaeoecology 223, 181-203.

Grimm, E. 1991: TILIA and TILIAGRAPH. Illinois State Museum, Springfield, Illinois.

Jankovská, V. \& Komárek, J. 2000: Indicative value of Pediastrum and other coccal green algae in palaeoecology. Folia Geobotanica $35,59-82$.

Khotinskiy, N. A. 1984: Holocene vegetation history. In Velichko, A. A. (ed.): Late Quaternary Environments of the Soviet Union, 179200. Longman, London.

Komárek, J. \& Jankovská, V. 2001: Review of the green algal genus Pediastrum; implication for pollen-analytical research. Bibliotheca Phycologica 108, 1-127.

Koshkarova, V. L., Karpenko, L. V. \& Orlova, L. A. 1999: The Holocene dynamics of vegetation and the upper forest limit in the Polar Urals. Russian Journal of Ecology 30, 102-106.

Kultti, S., Väliranta, M., Sarmaja-Korjonen, K., Solovieva, N., Virtanen, T., Kauppila, T. \& Eronen, M. 2003: Palaeoecological evidence of changes in vegetation and climate during the Holocene in the pre-Polar Urals, northeast European Russia. Journal of Quaternary Science 18, 503-520.

Kuvchinova, K. V. 1968: Climate. In Gerasimov, I. P. (ed.): Uralskie gory i Preduralie, 82-117. Nauka, Moscow.

Levkovskaya, G. M. 1967: Distribution of Pollen and Spores in the Recent Holocene Sediments on NW Siberia. Ph.D. dissertation. Institute of History of Material Culture RAS, St. Peterburg, 180 pp.

MacDonald, G. M., Kremenetski, C. V., Velichko, A. A., Cwynar, L. C., Riding, R. T., Goleva, A. A., Andreev, A. A., Borisova, O. K., Edwards, T. W. D., Hammarlund, D., Szeicz, J. M., Forman, S. \& Gataullin, V. I. 2000: Holocene treeline history and climate change across Northern Eurasia. Quaternary Research 53, 302-311.

Oksanen, P. O., Kuhry, P. \& Alexeeva, R. N. 2001: Holocene development of the Rogovaya River peat plateau, European Russian Arctic. The Holocene 11, 25-40.

Panova, N. K. \& Jankovska, V. 2000: Dynamics of vegetation on timberline of the Polar Urals during the Holocene. In Kuznetsov, O. L., Elina, G. A. \& Grabovik, S. I. (eds.): Dinamika bolotnykh ekosistem v Severnoi Evrazii v golotsene, 11-15. Karelian Scientific Center, Petrozavodsk (in Russian).

Panova, N. K., Jankovska, V., Korona, O. M. \& Zinov'ev, E. V. 2003. The Holocene dynamics of vegetation and ecological conditions of the Polar Urals. Russian Journal of Ecology 34, 219-230.

Paus, A., Svendsen, J. I. \& Matiouchkov, A. 2003: Late Weichselian (Valdaian) and Holocene vegetation and environmental history of the northern Timan Ridge, European Arctic Russia. Quaternary Science Reviews 22, 2285-2302.

Sarmaja-Korjonen, K., Kultti, S., Solovieva, N. \& Väliranta, M. 2003: Mid-Holocene palaeoclimatic and palaeohydrological conditions in north-eastern European Russia: a multi-proxy study of Lake Vankavad. Journal of Paleolimnology 30, 415-426.

Serebryanny, L., Andreev, A., Malyasova, E., Tarasov, P. \& Romanenko, F. 1998: Lateglacial and Early Holocene environment in the Russian Arctic. The Holocene 8, 323-330.

Shiyatov, S. G. 1964: Dynamics of the Upper Tree-Limit on the Eastern Slope of the Polar Ural Mts. Ph.D. dissertation. Institute of Plant and Animal Ecology RAS, Yekaterinburg, 200 pp.

Shiyatov, S. G. 1986: Dendrochonology of the Upper Tree-Limit in the Ural Mts. 136 pp. Nauka, Moscow (in Russian).

Surova, T. G. 1967: About vegetation development of Polar Urals during the Holocene. Vestnik Moskovskogo Universiteta 2, 66-74 (in Russian).

Surova, T. G. \& Troitsky, L. S. 1971: Dynamics of vegetation, climate, and glaciation in the Polar Ural Mts. during the Holocene 
according to palynological study. In Neistadt, M. I. (ed.): Palinologiya golotsena, 121-135. Nauka, Moscow (in Russian).

Surova, T. G., Troitsky, L. S. \& Punning, J.-M. 1975: Holocene palaeogeography and absolute chronology of the Polar Ural Mts. Eesti NSV Teaduste Akademia Tiometised. Keemia-geoloogia 24, 152-159 (in Russian).

Vaganov, E. A., Shiyatov, S. G. \& Mazepa, V. S. 1996: Dendrochonological Studies in Ural-Siberian Subarctic. 246 pp. Nauka, Novosibirsk (in Russian).
Väliranta, M., Kaakinen, A. \& Kuhry, P. 2001: Holocene climate and landscape evolution east of Pechora Delta, East-European Arctic. Quaternary Research 59, 335-344.

Velichko, A. A., Andreev, A. A. \& Klimanov, V. A. 1997: The dynamics of climate and vegetation in the tundra and forest zone during the Late Glacial and Holocene. Quaternary International 41/42, 71-96. 